\title{
ÀS MARGENS DO ARROIO
}

Guilherme Azambuja Castro é advogado e mestrando em Escrita Criativa na PUCRS.

E-mail: guilherme.castro.001@acad.pucrs.br

A prima foi até a margem, queria ver se hoje dava para botar lancha no arroio; os cabelos - úmidos, soltos - deixaram um odor agradável a xampu no alpendre, justo onde Marlon esmigalhava as pétalas de uma hortênsia seca.

Dava para botar, certamente. Em alguns minutos ela partiria direto à margem brasileira, e dali ao baile no Beira Mar.

Marlon observava-a de costas, a silhueta negra contra a água branca; vontade de se tocar, massagear o pênis que se manifestava como um bicho há muito encarcerado, tivesse ele coragem...

Na sala, o pai e o mais velho ajustavam as gravatas em frente ao espelho, do alpendre Marlon não os via; a mãe estava quase pronta, talvez faltasse um broche ou a maquiagem. Quando passava pelo alpendre, fazia-lhe um arremedo de cafuné, e que ele se comportasse com a avó. E a prima, a prima ainda estava lá, na margem, era só o que Marlon conseguia perceber.

Em seguida os quatro subiram na lancha do seu Mário, que já os aguardava no arroio, e partiram.

Da cozinha, a avó diz:

"Ôlha, m’ijo, el barquito", sua voz competia com o rádio, Barra del Chuy 46.5 FM, su verano mááás caliente!, "no ê lindo?", Brasil: veinteuna horas, cincuenta minutos. Uruguay: veinte horas cincuenta minutos, horario de vera..., "corta el arroyo como una tijera, verdad?".

Verdade, uma tesoura, Marlon olhou a lancha embicar na margem brasileira; era uma noite de águas lisas.

Comeu cenoura cozida, metade de um filé de peixe-rei, o arroz dispôs pelo prato em montinhos.

"A comer todo!", disse-lhe a avó sem levantar os olhos do carpim que cerzia envolto num ovo de madeira.

Marlon cruzou os braços, o gesto mudo pelo qual costumava pedir figos em calda à avó. Com um quase-sorriso, como quem diz vou ceder mas só desta vez, ela arrematou a costura, cortou a linha com os dentes e arrastou um banco até o armário aéreo. Subiu e, depois de enfiar o 
braço até o fundo abissal do armário, apalpar uma que outra coisa, trouxe à mesa um pote de Nescafé sem rótulo. “A ver... Qual ê nôsso segrediño?”, suspendia um figo no ar.

"Bico fechado?", a calda deslizava no garfo, pingava ora na toalha de mesa, ora no pulso dele.

"Tu padre... Si descubre, xá sabes."

"Não vai saber, vó. Te juro."

Serviu-lhe um, depois outro e mais outro; enormes, deliciosos, gordos figos. De colher na mão, Marlon partiu para o serviço. Comeu tudo, lambeu até as gotas salpicadas no pulso e pediu mais.

"M'ijo, ahora ê cama, eh."

Ele tentou mas não teve jeito. No fundo sabia, seu destino era mesmo a cama, o pai costumava voltar cedo dos bailes e teve um dia que os surpreendeu, ele e a avó, assistiam uma fita e tomavam mate-doce na sala. Foi o diabo. Mas a vovó conhece, ah, se conhece o choro do rapazinho, por isso disse-lhe, o pijama está passado e dobrado embaixo do travesseiro, a insulina na segunda gaveta da cômoda que é para aplicar amanhã de manhã, pois o senhor é grande o suficiente e já sabe a diferença entre brincadeira e obrigação; se quiser pode ler uma revistinha, "después a dormir, eh? Son horas".

Marlon obedeceu.

Línguas se tocam, pernas se entrelaçam, lá estão os dois, escondidos atrás do pinheiro do pátio. A vó disse e redisse, casa dela não é lugar pra safadezas, olha que eu conto tudo! E quando a virilha é tocada, a prima solta um gemido e segura o sexo do namorado por cima das calças, duro, inchado, pulsando, pulsando, ela quer? Eu vi tudo isso que vocês fizeram, vou contar pra vó, sim senhora. Quer. Logo à noite. No terreno abandonado do clube, enquanto o pai e a mãe dançam um twist do tempo deles no salão e o mais velho vomita nacos de peixe-rei, cenouras cozidas e um litro de champanhe no sanitário. Eles chegam ao terreno, aqui tem só a carcaça dum Fusca velho, o namorado diz baixinho, lhe morde o lóbulo esquerdo e o dente frisa no brinco. Ela sente o ventre gelar e deita no banco traseiro do Fusca. Amolece o corpo. Deixa livre a mão que lhe arria a calcinha até os tornozelos. Sussurra me come quando já é penetrada.

Marlon tocava-se debaixo dos lençóis. Uma dor surgia e ele parava, depois continuava: prima, pinheiro, clube - tocava-se e a dor vinha mais forte; terreno, fusca, calcinha, me come!

Tocava-se, tocava-se.

Algo iria irromper, sair de dentro. Algo. Não sabia o que era:

"Posso tomar mate-doce contigo?!", gritou à avó.

"Tu padre...", ela respondeu da sala, "Bien, bien." 
Marlon se levantou de um salto e caminhou com os pés enroscados nos lençóis até a porta. Desvencilhou-se deles e correu para o sofá:

"Que que tá passando, vó?"

"Un filme... Una serie... Que sé yo", ela tomava mate-doce num copo de vidro e comia biscoitos do saco.

O menino acomodou a cabeça no regaço da avó e foi cheirar a fragrância de pêssego, um perfume que ela só usava em casa, o pênis murchou. E com ele as imagens da prima.

"Tentaste las revistiñas, m'ijo?"

"Não adianta, não tenho sono, vó."

"Conta atê quinientos."

"Antes tu me dá um mate-doce?"

"Sabes muito ben lo que passa si te doy, no?"

"Morro?"

A avó procurou o que dizer, olhos fixos no teto. As palavras que ela queria não encontrou, então disse "eso pôdi", apenas isso, oferecendo-lhe o saco aberto.

Como um ratinho, Marlon roeu o biscoito durante o filme todo.

$$
01: 50
$$

O pessoal chegou do baile sem a prima.

A mãe foi até o quarto, Marlon fingia dormir. Ela acomodou o lençol no seu queixo, deulhe um beijinho na fronte e saiu.

O irmão, pelo ruído não lhe pareceu bêbado, nadinha mesmo. O irmão entrou e acendeu a vela que servia para um não acordar o outro com luz forte. Despiu-se, dependurou a camisa no cabide, deitou-se e assoprou a vela; a chama apenas tremeu.

"Ô, mano! Como tava o baile?"

"Achei que tavas dormindo... Bom. Bem bom."

"E bebeste?"

"Só um gole. Champanhe."

"Ah... E a prima?"

"Vem depois. Seu Mário hoje fica até as cinco."

"Ah... E por que não veio com vocês, hein?"

Não respondeu. $\mathrm{O}$ irmão não lhe respondia mais que três perguntas. Assoprou mais forte a vela e a chama agora desapareceu. Se podia ouvir, imersos no silêncio da casa, as ondinhas do arroio, os roncos do pai ressoando no corredor como um serrote lento e persistente, as eventuais palmas da mãe matando mosquitos na parede, e os ventiladores de teto girando-girando em cada quarto. 
Marlon levantou-se e foi até a sala. Ali, a avó esquecera o açucareiro e o copo cheio da erva-mate ainda molhada. Despejou duas colheradas de açúcar na erva e tomou o melhor matedoce do mundo. Quanto mais bebia, mais seca ficava a boca.

Sede, sentia muita.

E uma vontade de comer chocolate, figos em calda, marmelada, essas coisas boas da avó.

Foi à cozinha, alcançou o pote de Nescafé e levou-o à mesa. Nisso, um barulho lá fora, saltos altos trocavam a maciez da grama pelo cimento do alpendre; mas a sede era tanta, como se uma enorme pedra de sal se dissolvesse na língua, que não deu bola. Abriu o pote e, num pires, serviu-se dos figos.

\section{$02: 33$}

A campainha soou, o pai veio abrir. Sonolento, levava a chave à fechadura quando se surpreendeu com Marlon comendo àquela hora, absorto - o verde das frutas sobre a louça branca do pires era só o que ele via.

De sobressalto, o menino escondeu o pote atrás de si.

"O que é isso?!", perguntou o pai.

"Nada..."

O pai lançou-se contra ele, mesmo sem ver o doce sabia do que se tratava.

Por debaixo da mesa, Marlon conseguiu livrar-se das mãos pesadas que eram as do pai. Mas o pote escorregou-lhe das mãos e, ao chocar-se no piso, quebrou misturando figos e cacos de vidro numa espécie de vômito inesperado.

O pai olhou para o doce, olhou para o menino: "assim tu vai morrer, guri de merda, assim tu vai morrer...".

Marlon encolheu-se num canto.

“Assim tu vai morrer...", o pai dizia não mais ao menino, mas a si mesmo, só então abriu a porta à sobrinha. Apontando o chão, disse a ela para fazer o favor de dar um jeito nisso, e depois, como seguisse um conhecido ritual, entrou no quarto e começou a se vestir. 
Marlon permanecia no mesmo canto, a testa pressionada nos joelhos continha-lhe a dor, uma dor de cabeça que vinha tão e tão forte quanto a vontade de comer o doce, de lamber a calda grossa e verde que se estendia pelo chão como uma cobra. Danem-se os cacos de vidro, dane-se o pai, pensou, danem-se. Pegou um figo do chão e enfiou na boca.

A prima voltou com pá e vassoura:

"O tio mandou limpar essa sujeira."

"Ninguém vai limpar nada", Marlon respondeu.

A voz já era fraca, mal conseguia mastigar.

"O tio que mandou", a prima insistiu. Com a vassoura arrastava os figos espalhados, os figos que Marlon protegia com seus olhos diabéticos, para longe dele.

Naquele segundo quis mover-se, não pôde; quis jogar-se sobre o pote, sobre os cacos de vidro, sobre os figos aos poucos sendo aninhados na pá, não conseguiu. Sim, ele quis, ainda que se ferisse, doesse, sangrasse, melhor.

Ferir-se.

Talvez a chance de sentir o hálito da prima mais de pertinho. Ferido, ela viria ao seu encontro, encobriria a chaga com papel-toalha e diria "já já o corte sara, primo, não demora a dor também, pum, se vai!".

Marlon pensou que se isso acontecesse ofereceria a ela o seu ouro. Na boca. Daria a ela os figos para que os lábios que via agora num rosto fechado encobrisse devagarinho o bojo da fruta, enquanto o talo quem dera ficasse para sempre ali, em seus dedos.

Os pezinhos da prima, ainda amarrados às sandálias ajudavam a vassoura na empresa de agrupar cacos e figos na pá, mas os pés que ele desejava eram outros, eram aqueles que dançaram o baile inteiro e que ela entregaria cansados e mornos no colo dele, um gesto que significaria "quero ficar contigo, primo". Então, outro figo. Ele rasgaria em duas partes. Uma delas, comeria; a outra, colocaria sobre a língua da prima e que bom seria ver aqueles dentes lambuzados de calda, a língua meio torta levando a fruta para lá e para cá.

Já não discernia as imagens, as formas, e a prima despejando figos na lixeira era-lhe não mais que um vulto.

Distante, colorido, inalcançável.

$$
* * *
$$

Marlon sentiu as tábuas da lancha nas costas. No rosto tocava-lhe aquele que repetia, entre outras inaudíveis, as palavras: "rápido" e "hospital".

Seu Mário deu a partida.

Eram quase 3:00. E os ventiladores giravam em cada quarto. 